\title{
Nectar-foraging behavior of Euglossine bees (Hymenoptera: Apidae) in urban areas*
}

\author{
Margarita María LóPEZ-URIBE, Cintia Akemi OI, Marco Antonio Del LAMA \\ Laboratório de Genética Evolutiva de Himenópteros, Universidade Federal de São Carlos, Rodovia Washington \\ Luiz km 235, CEP 13565.905, São Carlos, São Paulo, Brazil
}

\author{
Received 30 August 2007 - Revised 11 January 2008 - Accepted 19 February 2008
}

\begin{abstract}
Euglossine bees have been described as long-distance pollinators because of their great flight capacities although flight capacity is not necessarily correlated to home range. Here we report the nectarforaging behavior of two euglossine species (Euglossa cordata and Eulaema nigrita) in urban areas and the predictive power of wing wear as an age estimator of these bees, using mark-recapture techniques at Thevetia peruviana trees. A total of 870 bees were marked. Recapture rates were $33 \%( \pm 19.2)$ for $E$. cordata and $25 \%( \pm 2.5)$ for E. nigrita. Only 7 bees were sighted at a different site from where they were first captured. More than $75 \%$ of the individuals showed site-constancy at trees for at least 30 days. Wing wear accumulation rate was variable among individuals and it was a poor predictor of age for E. cordata. Our data show that euglossine bees may have small foraging ranges in urban areas, indicating that home ranges greatly differ from their flight capacity and homing ability.
\end{abstract}

orchid bees / Euglossa cordata / Eulaema nigrita / mark-recapture / wing wear

\section{INTRODUCTION}

Euglossine bees have been described as potential long-distance pollinators of many neotropical plant species (Dressler, 1968). Several studies have shown that individuals of both sexes have the capacity for long-distance flight, and thus postulated large home ranges. Janzen (1971) released 12 females of $E u$ friesea surinamensis at 14-23 km away from their nests and found half of the females back in their nests by the end of the day. This was interpreted as evidence that E. surinamensis females have large home ranges. In a natural "mark-recapture experiment", Eulaema meriana (Oliver) males arrived to chemical baits carrying pollinaria of an orchid species found in high areas at least $40 \mathrm{~km}$ away (Dressler, 1982). These data highlighted the potentially

Corresponding author: M.M. López-Uribe, mm182@cornell.edu

* Manuscript editor: Jacqueline Pierre great dispersing abilities of euglossine bees because of the long distances they were able to fly.

However, flight capacities may not be directly correlated to natural foraging distances. The ability to return to the nest after longdistance displacement may be the result of landmark orientation rather than familiarity with a vast home range (Collett, 1996). Also, long distance flights when chemical baits are used for sampling euglossine males may not reflect natural foraging distances due to the high concentration of attractants used. Some studies have shown that euglossine bees do not forage for fragrances or nectar resources at sites $400 \mathrm{~m}$ away (Kroodsman, 1975; Schemske, 1981). Therefore, the extreme difference between flight capacity and the actual flight range of these bees may be due to the quality and spatial distribution of resources (Westphal et al., 2006).

Mark-recapture experiments are widely used in population ecology for estimating 
parameters such as population size, survival rates, longevity and dispersal (Andres and Rivera, 2001; Bischoff, 2003) among others. However, these parameters have not been estimated for euglossine populations because of the low or non-existent recapture rates when bees are marked at chemical baits (Kroodsman, 1975; Janzen, 1981; Ackerman and Montalvo, 1985; Folsom, 1985; Raw, 1989; Eltz et al., 1999; Otero and Sandino, 2003; Tonhasca et al., 2003). The low recapture rates resulting from these experiments have been interpreted as evidence for: (1) large population sizes, (2) long-distance dispersal capacities or (3) marking techniques affecting the probability of recapture. However, as euglossine bees easily lose tags from grooming behavior (Folsom, 1985), such explanations have not been verified and the study of these bees through individual marking has been difficult.

Knowledge of foraging behavior is necessary for understanding how bees use different resources. We conducted a mark-recapture experiment for two euglossine species, $E \mathbf{E}$ glossa cordata (Linnaeus) (EC) and Eulaema nigrita Lepeletier (EN), using Thevetia peruviana (Apocynaceae) trees as sampling sites to investigate their nectar-foraging behavior in urban areas. The specific questions addressed in this study were: (1) Do euglossine bees fly long distances between $T$. peruviana trees looking for nectar? (2) Does foraging behavior differ between females and males in urban areas? and (3) Is wing wear accumulation correlated with the time between recaptures of the individuals?

\section{MATERIALS AND METHODS}

\subsection{Study Site}

The study was conducted inside the urban area of the city of São Carlos (SP-Brazil) located between $21^{\circ} 30^{\prime} \mathrm{S} 47^{\circ} 30^{\prime} \mathrm{W}$ and $22^{\circ} 30^{\prime} \mathrm{S} 48^{\circ} 30^{\prime} \mathrm{W}$. The climate of the region is bimodal, with dry winters (April-September), wet summers (October-May) and an average rainfall of $1400 \mathrm{~mm}$. The native vegetation of the area was mainly composed of savannas, arboreal savannas and riparian forests, but it is currently very fragmented, with only $7 \%$ of its original coverage remaining (Soares et al., 2003).

Twelve sites of $T$. peruviana trees were sampled, located at linear distances ranging from 0.24$5.45 \mathrm{~km}$ apart. All sites were found on street sidewalks within the urban perimeter of the city of São Carlos. This exotic tree species was chosen as the sampling unit because (1) it is an important source of nectar for euglossine bees in the area, (2) it is actively visited by both females and males and (3) it is abundant in the urban landscape of several cities in the state of São Paulo (Brazil) (López-Uribe and Del Lama, 2007).

\subsection{Marking euglossine bees}

For four months in 2005 (Feb-Mar; Nov, NovDec) and seven months in 2006 (Jan-Jul), every site was sampled at least once every two weeks for a two-hour period. During the first two months, bees were marked for eight hours at one site and we observed two patterns: (1) bees were less frequent at flowers in the afternoon and (2) re-visitations of the same individuals at the same site increased after two hours of sampling. For this reason, the sampling sessions were reduced to a two-hour period between 6000 and $1200 \mathrm{~h}$, randomizing the starting time among the different sites to avoid biased recaptures of the same individuals. During the hot and rainy season, when bees were more abundant, trees were sampled twice per week. At times, especially during the dry and cold season, some sites were not sampled because of the lack of flowers in the trees. T. peruviana phenology in the city of São Carlos varied among individuals, probably due to differences in the quantity of water and light, the quality of the soil and the care provided by the owners of the plants.

Euglossines were collected in plastic bags while visiting $T$. peruviana flowers and later chilled on ice for three to five minutes until they were in torpor. A colored numbered plastic tag (Opalithplättchen) was glued on their thorax using fast-drying glue. For hairy bees such as E. nigrita, hair was carefully removed from the thorax before gluing the tag. Bees were kept in vials until they were active again to ensure the glue was dry and the tag was securely attached even after grooming. The vials were then opened until the bees found their way out and flew away. 


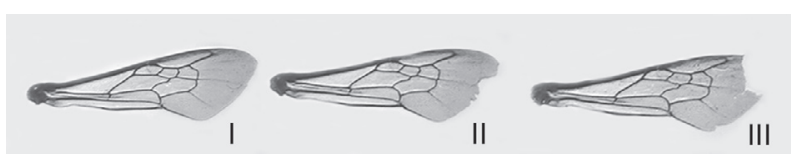

Figure 1. Standards showing the three categories of wing wear used for age estimation in Euglossa cordata (category I = no tears; category II = tears; category III = notches).

Table I. Sex ratios for the captured and recaptured (at least once) individuals of the euglossine species found in the Thevetia peruviana flowers. The Chi-square was used to test whether both sexes have the same recapture chance.

\begin{tabular}{lcccccc}
\hline & & Females & Males & Sex Ratio & $\chi^{2}$ & $P$ \\
\hline \multirow{2}{*}{ E. cordata } & Captured & 596 & 53 & $11: 1$ & $4.65^{* *}$ & 0.03 \\
& Recaptured & 163 & 5 & $32: 1$ & & \\
E. nigrita & Captured & 106 & 115 & $1: 1$ & 0.66 & 0.42 \\
& Recaptured & 18 & 27 & $1: 1$ & & \\
E. violacens & Captured & 4 & 1 & $4: 1$ & - & - \\
E. smaragdina & Recaptured & 1 & 0 & - & & - \\
& Captured & 2 & 1 & $2: 1$ & - & \\
\hline
\end{tabular}

\subsection{Data record and analysis}

For each specimen, we recorded the sex, date, time, collection site and degree of wing wear, which was classified into three categories (category $\mathrm{I}=$ no tears; category II = tears; category III = notches) (Fig. 1). Whenever an individual was captured in the flowers, it was photographed to record the gradual damage of wings.

Average and standard deviation for recapture rates and number of days at the same site were calculated. Recapture rates per site were estimated based on the number of bees marked versus the number of bees recaptured on different days at the same site. Individuals marked on the last day of sampling at each site were not included in the estimate of recapture rates. A chi-square test was used to test for equal recapture probabilities in males and females of both species. The onesample Kolmogorov-Smirnov test was used to test for Gaussian and Poisson distributions of the number of recaptures. To test for the predicting power of wing wear on the age of the bees, a linear regression model of the log-transformed data was performed. All statistical analyses were conducted using SPSS for Macintosh 11 (SPSS, 2002).

\section{RESULTS}

A total of 870 individuals $(\mathrm{EC}=649 ; \mathrm{EN}=$ 221) were marked during the sampling period.
Five E. violacens (Mocsáry) and three Exaerete smaragdina (Guérin-Méneville) were captured, marked and released, but only one E. violacens was re-sighted. Sex ratios (female:male) of captured individuals at trees were very different for $E$. cordata and $E$. nigrita (EC 11:1; EN 1:1) (Tab. I).The proportion of individuals marked and recaptured at least once varied among different sampling sites, but on average recapture rates were $33 \%$ for E. cordata $( \pm 19.2)$ and $25 \%$ for E. nigrita $( \pm 2.5)$. E. cordata females were recaptured up to seven times, but the frequency of recaptures did not fit a Poisson distribution $(Z=2.701$; $P=0.000$ ) (Fig. 2). E. nigrita individuals were recaptured up to five times and the recapture probabilities for females and males fit the Poisson distribution (females: $\mathrm{Z}=0.357$, $P=1.000$; males: $\mathrm{Z}=1.037, P=0.233)$.

Only seven females, six E. cordata $(3.6 \%)$ and one E. nigrita (2.3\%), were recaptured at a site different from where they were first captured and marked (Tab. II). Distances at which these bees were recaptured ranged from 0.24 to $1.02 \mathrm{~km}$ for $E$. cordata and $0.36 \mathrm{~km}$ for $E$. nigrita. The individual of $E$. cordata seen $1.02 \mathrm{~km}$ away from the first capture site was not seen again. The other six individuals were seen foraging in the same pair of sites (DPII-RB; BC-JB) and four of these bees were 


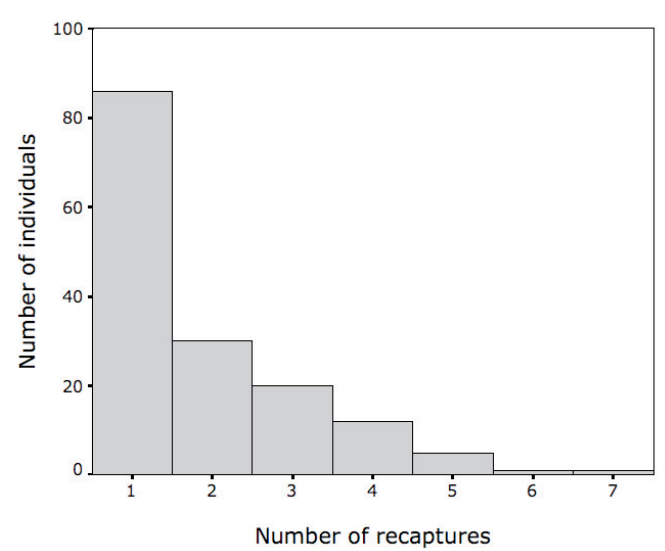

Figure 2. Frequency of the number of recaptures for Euglossa cordata females. The number of recaptures decreases drastically after the first recapture event but it does not fit the Poisson distribution $(\mathrm{Z}=2.701, P=0.000)$.

recaptured more than once at one of the sites. Two individuals visited both sites on the same day.

For both species, more than $75 \%$ of the individuals recaptured at least once were resighted within the first 30 days of sampling (EC 77\%; EN 93\%) (Figs. 3, 4). On average, E. nigrita males were recaptured at the same site for $10 \pm 8.3$ days $(\mathrm{n}=28)$ and females for $18 \pm 23.11$ days $(n=16)$ (Fig. 4). There was one E. nigrita female captured on February 3rd 2006 and recaptured 92 days later on May 6th. For E. cordata, the mean time females were re-sighted at the same site after marking was $25 \pm 28.34$ ( $\mathrm{n}=155$ ) (Fig. 3) but five individuals were recaptured more than 100 days after their first capture date. The longest time between the first and last recapture was of 170 days for an E. cordata female marked on February 8th 2006 and recaptured for the first time on July 28th 2006. There was not enough data for males of E. cordata to detect a pattern, however the few males recaptured during our experiments were not re-sighted after 10 days $($ Mean $=6 \pm 0.58 ; \mathrm{n}=5)$.

Most individuals of both species exhibited category I wing wear, indicating that the population is mainly composed of newly emerged individuals (but see below). However, wing wear showed to be a poor predictor of the age of $E$. cordata $\left(r^{2}=0.197 ; F=28.538\right.$; $P=0.000$ ). This is probably due to the several outliers and extreme values for 0 and 1 changes that suggest the accumulation rate varies significantly among individuals (Fig. 5). There were not enough data to test the predictive power of wing wear for the age of $E$. nigrita.

\section{DISCUSSION}

\subsection{Recapture rates and sex ratio at flowers}

To our knowledge, the data presented here show the highest recapture rates reported for euglossine bees to date (Kroodsman, 1975; Janzen, 1981; Ackerman and Montalvo, 1985; Raw, 1989; Otero and Sandino, 2003; Tonhasca et al., 2003). Furthermore, the marking method described here using numbered tags is different from other previously used (e.g. painted colors, varnish or manual wing wear) painted colors, varnish or manual wing wear because the identification of each bee is possible. Numbered tags allow the recording of the life history of each individual, which is necessary for the estimation of population parameters such as migration rates, survival and population size.

There is a higher probability of recapturing individuals at constant resources such as flowers than at artificial baits. The sampling method used on this study may partially explain the high recapture rates we found. Both males and females were site-constant at $T$. peruviana trees, although for different periods as females of both species visited the same sites for more days than males. Because females are central-place foragers that come back to the nest to feed progeny and defend them from parasites and predators, they probably have the same foraging territory for longer periods than males, which tend to be more mobile (Ne'eman et al., 2006). Nonetheless, males were also repeatedly recaptured suggesting that they are also site-constant regarding nectar resources, in support of the "non-vagabond hypothesis" (Ackerman et al., 1982). Although euglossine males leave the nest after emergence, they probably establish territories and 
Table II. List of euglossine individuals captured at different sites from where they were first marked in the city of São Carlos (SP-Brazil). Date, names of the sites where bees were captured, linear distance between sites $(\mathrm{km})$ number of days between recaptures. The names of the sites correspond to the streets where the trees were located $(\mathrm{RB}=$ Rui Barbosa; DPII $=$ Dom Pedro II; TL $=$ Totó Leite; JB = José Benetti, BC = Bernardino de Campos).

\begin{tabular}{|c|c|c|c|c|c|}
\hline \multirow{2}{*}{ Species } & \multicolumn{3}{|c|}{ Date and locality of capture } & \multirow{2}{*}{$\begin{array}{c}\text { Distance } \\
(\mathrm{km})\end{array}$} & \multirow{2}{*}{$\begin{array}{c}\text { Days between } \\
\text { captures }\end{array}$} \\
\hline & 1st capture & 2nd capture & 3rd capture & & \\
\hline E. cordata & 15-Feb, RB & 16-Feb, DPII & 21-Feb, RB & 0.24 & 1,5 \\
\hline E. cordata & 16-Feb, DPII & 21-Feb, RB & 11-Mar, DPII & 0.24 & 5,18 \\
\hline E. cordata & 16-Feb, DPII & 18-Feb, RB & & 0.24 & 2 \\
\hline E. cordata & 21-Feb, RB & 21-Feb, DPII & 11-Mar, DPII & 0.24 & 0,18 \\
\hline E. cordata & 30-Mar, BC & 8-Apr, JB & & 0.36 & 9 \\
\hline E. cordata & 15-Feb, TL & 18-Feb, RB & & 1.02 & 3 \\
\hline E. nigrita & 21-Nov, JB & 28-Nov, JB & 28-Nov, BC & 0.36 & 7,0 \\
\hline
\end{tabular}

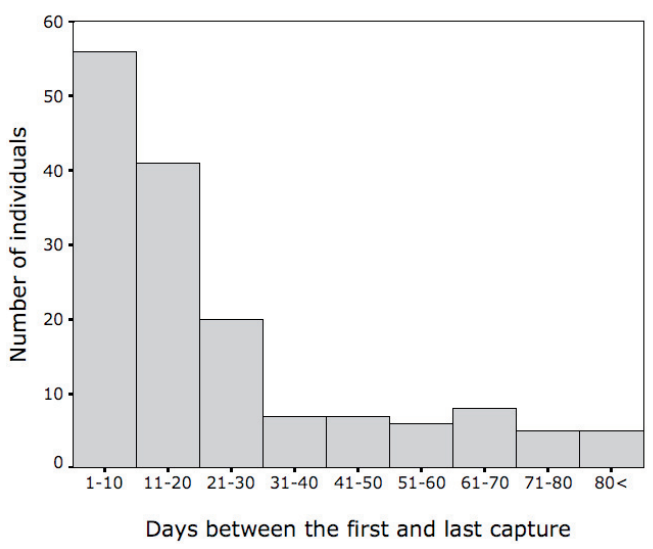

Figure 3. Histogram showing the number of days between the first and the last recapture for the $\mathrm{Eu}$ glossa cordata females recaptured at least once.

stay there as residents for some time (Janzen, 1981). This is supported by the fact that males regularly return to resting places to sleep solitarily or in aggregations that can last over one month (Silva and Garófalo, 2004).

Sex ratio for $E$. cordata was strongly female-biased and the recapture probability for each sex was significantly different from the capture probability (Tab. I). It is likely that the female-biased capture rates of E. cordata at flowers are the result of differences in the quantity of nectar that females and males demand for their foraging activities. Females have to forage for nectar, pollen and resins for themselves and their broods, whereas males only have to forage for themselves. Nonethe- less, the sex ratio for E. nigrita was 1:1 for captures and recaptures. We believe males of E. nigrita use T. peruviana flowers as a nectar resources and resting places, as males were observed several times motionless inside flowers before $600 \mathrm{~h}$. This use of $T$. peruviana flowers by euglossine males was previously described for E. cingulata (Dodson, 1966). Therefore, we suggest the site-constancy some males of this species showed at these sites is also due to the use of flowers as resting places.

\subsection{Foraging behavior}

Only seven individuals were seen at a different place from where they were first captured and marked suggesting that euglossine bees, despite their impressive capacity for longdistance flight, do not necessarily forage over a large area for nectar when they establish a foraging territory. Such results are probably due to the foraging range of individuals depending on the availability and distribution of resources in the area. Body size has been proved to be a good predictor of foraging distance in bees (Greenleaf et al., 2007). However, in the scale of our study, we did not find a significant difference in the foraging range of the largebodied E. nigrita and the small-bodied E. cordata.

Bees are generally resource-selective for pollen but not for nectar, therefore foraging areas for these two resources are probably different. E. cordata and E. nigrita visit tubular nectar-rich flowers of native and 


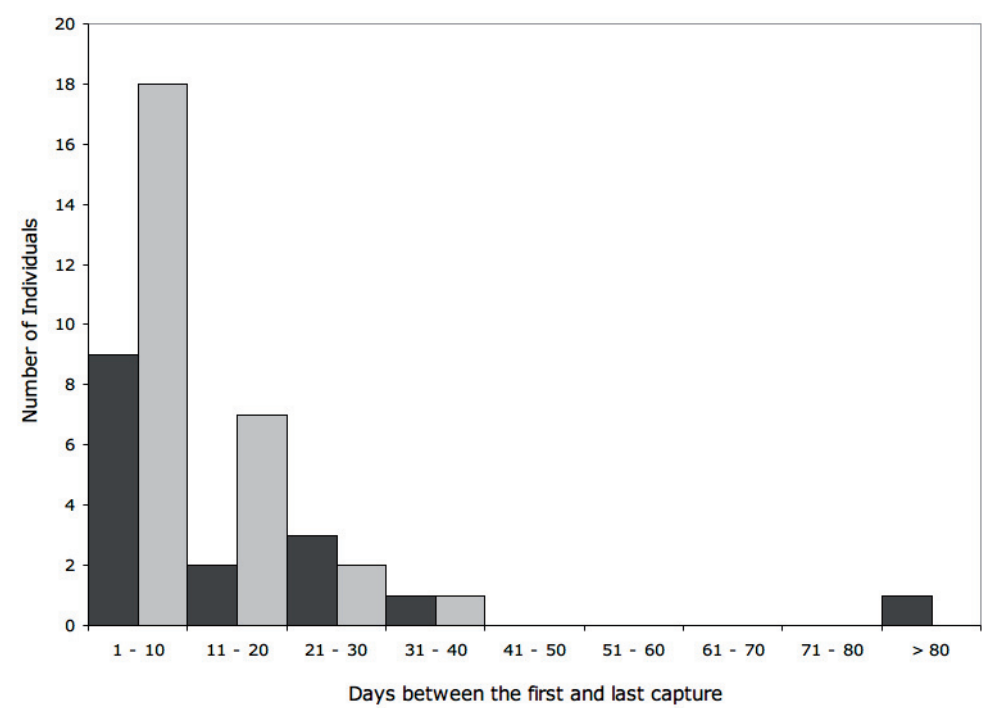

Figure 4. Histogram showing the number of days between the first and the last recapture for Eulaema nigrita individuals recaptured at least once (Black $=$ females; Gray $=$ males).

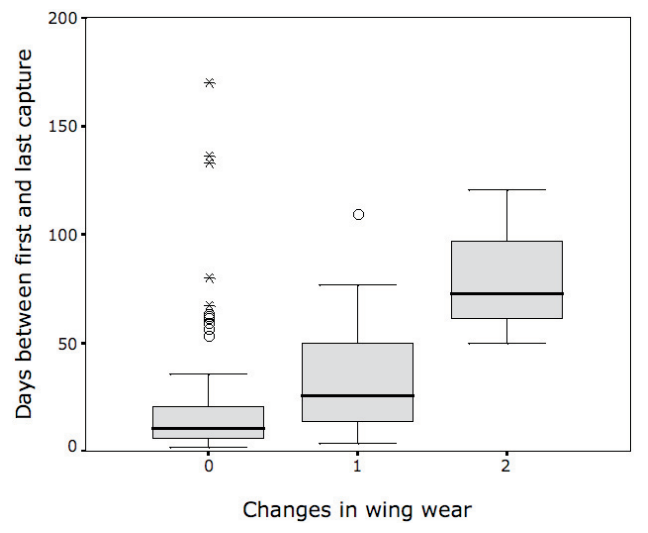

Figure 5. Boxplot indicating medians, quartiles, outliers $\left(^{\circ}\right)$ and extremes $(*)$ for the time between captures given the change in wing wear for $E u^{-}$ glossa cordata. Class 0 groups individuals with no changes; class 1 groups changes from I $\rightarrow$ II and II $\rightarrow$ III; and class 2 groups changes from I $\rightarrow$ III.

introduced Apocynaceae, Bignoniaceae and Convolvulaceae plants found in urban areas of the state of São Paulo (Silva et al., 2003). Tecoma stans (Bignoniaceae), which is another exotic species abundant in the urban landscape, has been reported as an important nectar resource for euglossines in the area (Silva et al., 2007). However, our data indicate that euglossines prefer $T$. peruviana as nectar resource. In three out of the 12 sites sampled in the city of São Carlos, T. stans trees were also present and only once $E$. cordata was seen visiting the $T$. stans flowers. This preference validates the use of $T$. peruviana for the study of the nectar-foraging behavior of this group of bees in urban areas.

One of the most interesting attributes of the tribe Euglossini is that they are the only group among the corbiculate bees that shows plasticity in social behavior, including solitary, communal and primitively eusocial species. E. cordata is a primitively eusocial species in which nests are started by a solitary bee. Around $50 \%$ of the daughters of the following generation stay in the nest with their mother and some sisters to establish a social group with one dominant female and one to several subordinates (Garófalo, 1985). Studies on the social behavior of E. cordata reported an egg-laying females that stayed in the nest for 191 days, whereas the foraging female that stayed the longest in the nest was for 53 days. We recaptured five females foraging on $T$. flowers for more than 100 days. These data suggest one or a combinations of the following: (1) foraging females of this species may be active longer than previously thought, 
(2) bees are less exposed to predation in urban ecosystems or (3) foraging and egg-laying females can exchange roles in the nest. This role-switching behavior has been described for other Euglossa species, such as E. townsendi (Augusto and Garófalo, 2004), but not for $E$. cordata (Garófalo, 1985). Previous studies addressing the longevity of euglossine reported one $E$. nigrita females that lived for 76 days in a flight cage (Ackerman and Montalvo, 1985). In our data, the longest time between the first and the last recapture registered for E. nigrita was 92 days, but $95 \%$ of the individuals were seen foraging for less than 40 days.

\subsection{Wing wear}

Wing wear has been used as a common age estimator of euglossines (Zimmerman and Madriñan, 1988; Eltz et al., 1999) and other groups of bees (Cartar, 1992; Mueller and Wolf-Mueller, 1993). However, variation in the accumulation rate of wing damage among individuals limits its use for age determination in euglossines (Eltz et al., 1999; this study). Our data show that presence of wing wear was a good indicator of old age in E. cordata bees, but not all old bees presented worn wings. Even though these results may be partially explained by specific conditions of the urban study area (e.g., less predation, shorter flight times), the large variation in the accumulation of wing wear limits its use as an accurate predictor of age in bees. The correlation between wing wear and age should be tested in each species and not merely assumed, as changes in the wing margin are not always gradual. For example, it has been observed that wings of newly emerged $E$. nigrita individuals are already worn due to the contact wings have with the harsh internal surface of the cells (Del Lama, unpublished data).

\subsection{Euglossine bees in urban areas}

Euglossine bees were long believed to be restricted to unperturbed areas because of their close coevolutionary relationship with orchids (Dressler, 1968). However, there is increasing evidence that many "orchid bee" species can maintain large and stable populations in perturbed or modified ecosystems such as farmlands and urban areas where native orchid species may not be available (Otero and Sandino, 2003; Pemberton and Wheeler, 2006). Particularly, E. cordata and E. nigrita are generalist species that prefer open disturbed areas and may be considered bioindicators of modified habitats (Tonhasca et al., 2003; Milet-Pinheiro and Schlindwein, 2005). It is worth noticing that E. cordata is a small short-tongued species, but is still able to exploit different food resources and to forage in high-temperature and low-humidity conditions (Raw, 1989; Milet-Pinheiro and Schlindwein, 2005). Our results suggest that E. cordata does not fit into the morphometric trend of large-sized long-tongued bees that prefer open places and small-sized short-tongued bees that prefer forested areas, proposed by Otero and Sandino (2003).

Several studies indicate that urbanized areas are suitable habitats for bee species depending on their food requirements and nesting habits (McIntyre and Hostetler, 2001; Zanette et al., 2005; McFrederick and LeBuhn, 2006). The euglossine species studied here may be favored in urban areas because they are polylectic and nest in cavities, features shared by other species of the Euglossini tribe (Dressler, 1982). Urban areas are potential refuges for the maintenance of some euglossine bee species, some of which may show high frequencies of diploid males due to genetic erosion caused by fragmentation and degradation of the habitat (Roubik et al., 1996; Zayed et al., 2004; López-Uribe et al., 2007; but see Takahashi et al., 2001). Thus, it is important to increase the quantity and quality of gardens and public squares in the cities to keep suitable habitats for these important native pollinators in urban areas.

\section{CONCLUSION}

The present study demonstrates that females and males of two euglossine species are site-constant foragers for some period. Our data also indicate that the home ranges of these 
strong fliers are not necessarily as large as previously thought, when foraging territories are established and provide enough resources. Homing ability of euglossine bees (e.g., using landmarks visible from a long distance) may explain their capacity of returning to their nest from long-distance releases without implying that they are using the whole area for foraging. As chemical baits can attract individuals from kilometers away, the use of baits as a sampling method may force males to fly further than they may normally, in response to strong attraction to rare aromatic compounds and not necessarily because they are within their home range. Therefore, whenever possible it is important to use natural resources for sampling to identify the actual foraging ranges of euglossine bees. Future studies are needed to investigate home ranges in other habitats to establish how foraging behavior changes in relation to the spatial distribution of resources in each particular ecosystem.

\section{ACKNOWLEDGEMENTS}

We want to thank the agencies $\mathrm{CNPq}$ (No. 475935/04-7), CAPES and FAPESP for the financial support to this project; R.O. Souza, F.T.T. Hanashiro and D. D'Assunção for their help in the field work; and A. Smith, S. Tierney, S. Ramírez and two anonymous reviewers for comments on the manuscript.

Comportement de butinage du nectar des abeilles euglossines (Hymenoptera : Apidae) en zones urbaines.

Euglossa cordata / Eulaema nigrita / marquagerecapture / distance de vol / usure de l'aile / estimation âge

Zusammenfassung - Nektarsammelverhalten von Euglossinen Bienen (Hymenoptera: Apidae) in Stadtgebieten. Euglossine Bienen (Prachtbienen) werden im allgemeinen als Weitdistanzbestäuber eingestuft, die grosse Sammelgebiete abdecken können. Sie sind dazu in der Lage aufgrund ihrer grossen Flugkapazität und dies obwohl Flugkapazität nicht notwendigerweise mit dem Heimatradius korreliert sein muss. In dieser Arbeit untersuchten wir das Nektarsammelverhalten von zwei Prachtbienenarten in Stadtgebieten, und wir bewerteten die Aussagekraft des Flügelabnutzungsgrads für die Altersabschätzung.
Wir beschreiben zudem eine effiziente Methode zur Markierung dieser Bienen, die Etiketten leicht durch ihr intensives Putzverhalten verlieren können. Weibchen und Männchen von Euglossa cordata $\left(\mathrm{n}_{w}=596 ; \mathrm{n}_{m}=53\right)$ und von Eulaema nigrita $\left(\mathrm{n}_{w}=106 ; \mathrm{n}_{m}=115\right)($ Tab. I) wurden markiert und später auf blühenden Bäumen der Art Thevetia peruviana (Apocynaceae) in einem Umkreis von $0,24-5,45 \mathrm{~km}$ im Stadtgebiet von São Carlos (SP, Brasilien) wiedergefangen. Die mittlere Wiederfangrate für $E g$. cordata lag bei $33 \%( \pm 19,2)$ und die für El. nigrita bei $25 \%$ $( \pm 2,5)$. Von den 213 wiedergefangenen Bienen wurden jedoch nur sieben an einem anderen Ort wiedergefangen als dem, an dem sie zuerst gefangen und markiert worden waren (Tab. II). Über $75 \%$ der Bienen beider Arten zeigten ausserdem eine Ortskonstanz im Sammelverhalten an den Bäumen über mindestens 30 Tage hinweg. Bei Männchen war der Zeitraum allerdings kürzer als bei Weibchen (Abb. 3 und 4). Diese Ergebnisse weisen daraufhin, dass Prachtbienen bevorzugt über kurze Distanzen hinweg Nektar sammeln, dass sie ihre Sammelterritorien jedoch nach einiger Zeit wechseln können. Der Flügelabnutzungsgrad erwies sich als individuell stark variabel und schien bei Eg. cordata kein guter Altersindikator zu sein (Abb. 5). Unsere Daten zeigen, dass Euglossinen in Stadtgebieten aufgrund der Verteilung von Blüten relativ kleine Sammelgebiete haben können. Dies bedeutet, dass sich Heimatradien stark von den Faktoren Flugkapazität und Heimfindungsvermögen unterscheiden können.

Prachtbienen / Euglossa cordata / Eulaema nigrita / Markierung-Wiederfang / Flügelabnutzung

\section{REFERENCES}

Ackerman J.D., Montalvo A.M. (1985) Longevity of euglossine bees, Biotropica 17, 79-81.

Ackerman J.D., Mesler M.R., Lu K.L., Montalvo A.M. (1982) Food-foraging behavior of male Euglossini (Hymenoptera: Apidae): Vagabonds or trapliners? Biotropica 14, 241-248.

Andres J.A., Rivera A.C. (2001) Survival rates in a natural population of the damselfly Ceriagrion tenellum: effects of sex and female phenotype, Ecol. Entomol. 26, 341-346.

Augusto S.C., Garófalo C.A. (2004) Nesting biology and social structure of Euglossa (Euglossa) townsendi Cockerell (Hymenoptera, Apidae, Euglossini), Insect. Soc. 51, 400-409.

Bischoff I. (2003) Population dynamics of the solitary digger bee Andrena vaga Panzer (Hymenoptera, Andrenidae) studied using mark-recapture and nest counts, Popul. Ecol. 45, 197-204.

Cartar R.V. (1992) Morphological senescence and longevity - an experiment relating wing wear and 
life-span in foraging wild bumble bees, J. Anim. Ecol. 61, 225-231.

Collett T.S. (1996) Short-range navigation: does it contribute to understanding navigation over longer distances? J. Exp. Biol. 199, 225-226.

Dodson C.H. (1966) Ethology of some bees of the tribe Euglossini (Hymenoptera: Apidae), J. Kans. Entomol. Soc. 39, 607-629.

Dressler R.L. (1968) Pollination by euglossine bees, Evolution 22, 202-210.

Dressler R.L. (1982) Biology of the orchid bees (Euglossini), Annu. Rev. Ecol. Syst. 13, 373-392.

Eltz T., Whitten W.M., Roubik D.W., Linsenmair K.E. (1999) Fragrance collection, storage, and accumulation by individual male orchid bees, J. Chem. Ecol. 25, 157-176.

Folsom J.P. (1985) Dos nuevas técnicas para capturar y marcar abejas machos de la tribu Euglossini (Hymenoptera: Apidae), Actual. Biol. 14, 20-25.

Garófalo C.A. (1985) Social structure of Euglossa cordata nests (Hymenoptera: Apidae: Euglossini), Entomol. Gen. 11, 77-83.

Greenleaf S.S., Williams N.M., Winfree R., Kremen C. (2007) Bee foraging ranges and their relationship to body size, Oecologia 153, 589-596.

Janzen D.H. (1971) Euglossine bees as long-distance pollinators of tropical plants, Science 171, 203205.

Janzen D.H. (1981) Bee arrival at two Costa Rican female Catasetum orchid inflorescences, and a hypothesis on euglossine population structure, Oikos 36, 177-183.

Kroodsman D.E. (1975) Flight distances of male euglossine bees in orchid pollination, Biotropica 7, 71-72.

López-Uribe M.M., Del Lama M.A. (2007) Molecular identification of species of the genus Euglossa Latreille (Hymenoptera: Apidae: Euglossini), Neotrop. Entomol. 36, 712-720.

López-Uribe M.M., Almanza M.T., Ordóñez M. (2007) Diploid male frequencies in Colombian populations of euglossine bees (Hymenoptera: Apidae: Euglossini), Biotropica 39, 660-662.

McFrederick Q.S., LeBuhn G. (2006) Are urban parks refuges for bumble bees Bombus spp. (Hymenoptera: Apidae)?, Biol. Conserv. 129, 372-382.

McIntyre N.E., Hostetler M.E. (2001) Effects of urban land use on pollinator (Hymenoptera: Apoidea) communities in a desert metropolis, Basic Appl. Ecol. 236, 209-218.

Milet-Pinheiro P., Schlindwein C. (2005) Do euglossine males (Apidae, Euglossini) leave tropical rainforest to collect fragrances in sugarcane monocultures?, Rev. Bras. Zool. 22, 853-858.

Mueller U.G., Wolf-Mueller B. (1993) A method for estimating the age of bees: Age-dependent wing wear and coloration in the wool-carder bee Anthidium manicatum (Hymenoptera: Megachilidae), J. Insect Behav. 6, 529-537.

Ne'eman G., Shavit O., Shaltiel L., Shmida A. (2006) Foraging by male and female solitary bees with implications for pollination, J. Insect Behav. 19, 383-401.

Otero J.T., Sandino J.C. (2003) Capture rates of male euglossine bees across a human intervention gradient, Chocó region, Colombia, Biotropica 35, 520-529.

Pemberton R.W., Wheeler G.S. (2006) Orchid bees don't need orchids: Evidence from the naturalization of an orchid bee in Florida, Ecology 87, 19952001.

Raw A. (1989) The dispersal of euglossine bees between isolated patches of eastern Brazilian wet forest (Hymenoptera, Apidae), Rev. Bras. Entomol. 26, 243-255.

Roubik D.W., Weight L.A., Bonilla M.A. (1996) Population genetics, diploid males, and limits to social evolution of euglossine bees, Evolution 50, 931-935.

Schemske D.W. (1981) Floral convergence and pollinator sharing in two bee-pollinated tropical herbs, Ecology 62, 946-954.

Silva A.C.A., Garófalo C.A. (2004) Sleeping aggregation of males of Euglossa melanotricha Moure, 1967 (Hymenoptera, Apidae, Euglossini), 8th IBRA Int. Conf. on Tropical Bees and VI Encontro sobre Abelhas, p. 547, Ribeirão Preto (SP), Brazil.

Silva C.I., Augusto S.C., Moscheta I.S. (2003) As abelhas euglossini e suas fontes de recursos florais, VI Congr. Ecol. Brasil, Vol. I, pp. 80-81, Fortaleza.

Silva C.I., Augusto S.C., Sofia S.H., Moscheta I.S. (2007) Diversidade de abelhas em Tecoma stans (L.) Kunth (Bignoniaceae): Importância na polinização de frutos, Neotrop. Entomol. 36, 331-341.

Soares J.J., Silva D.W., Lima M.I.S. (2003) Current state and projection of the probable original vegetation of the São Carlos region of São Paulo State, Brazil, Braz. J. Biol. 63, 527-536.

SPSS v.11.0.4 (2002) SPSS Inc. Chicago, IL.

Takahashi N.C., Peruquetti R.C., Del Lama M.A., Campos L.A.O. (2001) A reanalysis of diploid male frequencies in euglossine bees (Hymenoptera: Apidae), Evolution 55, 1897 1899.

Tonhasca A.J., Albuquerque G.S., Blackmer J.L. (2003) Dispersal of euglossine bees between fragments of the Brazilian Atlantic forest, J. Trop. Ecol. 19, 99-102.

Westphal C., Steffan-Dewenter I., Tscharntke T. (2006) Foraging trip duration of bumblebees in relation to landscape-wide resource availability, Ecol. Entomol. 31, 389-394.

Zanette L.R.S., Martins R.P., Ribeiro S.P. (2005) Effects of urbanization on Neotropical wasp and bee assemblages in a Brazilian metropolis, Landsc. Urban Plan. 71, 105-121.

Zayed A., Roubik D.W., Packer L. (2004) Use of diploid male frequency data as an indicator of pollinator decline, Proc. R. Soc. Lond. B. (Suppl.) 271, S9-S12.

Zimmerman J.K., Madriñan S. (1988) Age structure of male Euglossa imperialis (Hymenoptera: Apidae: Euglossini), J. Trop. Ecol. 4, 303-306. 